\title{
Deceit, Self-Interest, and Censorship: Problems at the Bookbinders in Early Modern England
}

\author{
Matthew Day
}

$\mathrm{O}$ N 25 December 1551, Sir William Pickering, English ambassador to the French court, wrote to Sir William Cecil, secretary of state, sending him some books including a "New Testament in Greek; l'Horloge de Princes; le Discours de la Guerre de Laugnay, and notes to the Ethics of Aristotle." ${ }^{1}$ No doubt Cecil was pleased, but he was probably disap-

1. William B. Turnbull, ed., Calendar of State Papers, Foreign, Edward VI $1547^{-1553}$ (London: Longman, Green, Longman, and Roberts, 1861), 205. For Sir William Pickering see Susan Doran, "Pickering, Sir William (1516/17-1575)," Oxford Dictionary of National Biography (Oxford: Oxford University Press, 2004), doi:10.1093 /ref:odnb/22212; for Sir William Cecil, see Wallace T. MacCaffrey, "Cecil, William, first Baron Burghley (1520/21-1598)," Oxford Dictionary of National Biography, doi:10.1093/ref:odnb/4983. Not all the books are identifiable, but two of them may be Antonio de Guevara, L'Orloge des princes, trans. René Berthault (Paris, 1550) and perhaps the Florence (1550) or Venice (1551) editions of Aristotle, L'Ethica d'Aristotile, trans. Bernardo Segni. For a discussion of this incident in the context of humanism see Warren Boutcher, "Vernacular Humanism in the Sixteenth Century," in The Cambridge Companion to Renaissance Humanism, ed. Jill Kraye (Cambridge: Cambridge University Press, 1996), 191-92.

Matthew Day (Newman University, Genners Lane, Bartley Green, Birmingham B 32 3NT, UK, m.day@newman.ac.uk) is Reader in Early Modern Literature and Book History at Newman University and a Steering Group Member of the Centre for Printing History and Culture (www.cphc.org.uk). He researches on the materiality of the text and has a special interest in the intersection of travel literature and print culture in the early modern period.

PBSA 112:1 (2018): 1-25 (C) 2017 Bibliographical Society of America.

All rights reserved. $0006-128 \mathrm{X} / 2018 / 0112-0001 \$ 10.00$ 
pointed to learn that others "for lack of leisure could not be finished" and would not be forthcoming, while among those that were sent, the "binder's haste may be perceived by one of those seen being neither ruled nor washed." Pickering's comments reveal how the performance of the bookbinder deleteriously affected the quality of the book's appearance. The failure to "rule" the book (put decorative ruled lines on it) or to "wash" it (probably rub it with glue to ensure that gold leaf adhered to it) meant that the book received by Cecil was not as attractive as Pickering intended. However, this was as nothing compared with what was to come. Four days later Pickering wrote to Cecil again updating him on the books: "as for Euclid and Machiavelli, they were so buggerly bound that he burnt them both." ${ }^{3}$ Quite what made the second set so unpalatable remains a mystery, but in addition to highlighting the problems that owners might encounter at the bookbinders, the burning also demonstrates how poorly bound books could get destroyed, suggesting an inherent bias towards betterbound books amongst surviving copies.

Pickering's criticism of the first set of books concerns their appearance. Despite their poor dress, there is nothing to suggest the contents were inadequate, or that any of the leaves were misbound or omitted. That such problems were possible is testified to by instructions for binders intended to prevent such errors and by modern-day library catalogue entries giving details of erroneously bound volumes. ${ }^{4}$ Authors in the early modern period certainly understood that books might be incorrectly compiled and used the concept to their advantage. The first English edition of Bartolomé de las Casas's account of Spanish colonization in South America and the West Indies was entitled The Spanish Colony (1583), and constituted a translation of his Brevisima relación de la destrucción de las Indias (1552). Its running header, "The Spanish cruelties," revealed the work's agenda, and the English version included an excerpt from a letter which "contayned things fearefull, even to astonishment." The passage was included even though

2. Turnbull, Calendar of State Papers, 205-6.

3. Ibid., 206.

4. On instructions to bookbinders see B. J. McMullin, "Printers' Instructions to Binders," Papers of the Bibliographical Society of America 104, no. 1 (2010): 77-104. A search of SOLO (Search Oxford Libraries Online: http://solo.bodleian.ox.ac.uk /primo_library/libweb/action/search.do) under the term "misbound" produces 2,445 items for the period 1 January 1500-1 January 1800 . Numerous items are in bindings from the early modern period. 
it had neither "beginning [n]or ending"; its fragmentary nature and inclusion were explained away on the grounds that "the binder eyther forgot, or lost a leafe or two" of the work. ${ }^{5}$ It is impossible to know whether the claim was true or an excuse to provide only an excerpt of a text that the translator/ author M. M. S. did not wish to print in full. Either way, the bookbinder's failure in a culture where the usefulness of a book depended in large part on its physical form provided an explanation for an incomplete text. M. M. S. expected a shared understanding among readers that a text might get damaged at the bookbinders.

Nor were problems in the binding process the only way in which authors exploited the processes of book production to make a polemical point. Writers' awareness of the physical form of the book in the early modern period has been well evidenced by a number of literary critics. ${ }^{6}$ However, they have not drawn attention to the opportunities that the binding process offered to those who wished to satirize their opponents. Thus, in his Anti-Sozzo, sive Sherlocismus Enervatus: in Vindication of some Great Truths Opposed, Vincent Alsop, a leading Presbyterian of the Restoration period, satirized William Sherlock, a Church of England clergyman and controversialist. ${ }^{7}$ For Alsop, the contents of Sherlock's A Discourse Concerning the Knowledge of Jesus Christ, and our Union and Communion with Him (1674), seemed so unrelated to the title that Alsop suggested, "through some Oversight, either in the Collator, or

5. Bartolomé de las Casas, The Spanish Colony or Brief Chronicle of the Acts and Gests of the Spaniards in the West Indies, trans. M. M. S. (London: [Thomas Dawson] for William Brome, 1583), $\mathrm{M}_{4}^{\mathrm{v}}$.

6. Evelyn B. Tribble, Margins and Marginality: The Printed Page in Early Modern England (Charlottesville: University of Virginia Press, 1993); Wendy Wall, The Imprint of Gender: Authorship and Publication in the English Renaissance (Ithaca, NY: Cornell University Press, 1993); Heidi Brayman Hackel, Reading Material in Early Modern England (Cambridge: Cambridge University Press, 1997); Cathy Shrank, "'These Fewe Scribbled Wordes': Representing Scribal Intimacy in Early Modern Print," Huntington Library Quarterly 67 (2004): 295-314; Michael Saenger, The Commodification of Textual Engagements in the English Renaissance (Aldershot: Ashgate, 2006); Helen Smith and Louise Wilson, eds., Renaissance Paratexts (Cambridge: Cambridge University Press, 2011).

7. William Lamont, "Alsop, Vincent (bap. 1630, d. 1703)," Oxford Dictionary of National Biography, doi:10.1093/ref:odnb/424; William E. Burns, "William Sherlock, (1639/40-1707)," Oxford Dictionary of National Biography, doi:10.1093/ref: $\mathrm{odnb} / 25381$. 
Binder, a wrong Title-page had been praefixt to the Book." Here the processes of book production in which different sections of a book were combined to make a complete work provided an opportunity to pretend that the system had broken down. Alsop's decision to attack Sherlock for the perceived irrelevance of the title by drawing attention to the process of production is a reminder of the fragmentary nature of the early modern book in its unbound state and the consequent importance of the binding process to its coherence. Misbound books, whether through the bringing together of the wrong gatherings or through the binding of the correct gatherings in the wrong order, were clearly something early modern authors and readers understood and were one of the hazards of the early modern readers' experience. ${ }^{9}$

These three examples indicate some of the difficulties of the binding process and the discourses about binders which played out in the early modern period. The "cruelties perpetrated upon books by the ignorance or carelessness of binders" exemplify different aspects of the process: Sir William Pickering focused on the decorative aspects of the book; M. M. S. drew attention to missing pages; Alsop hinted at the possibilities of misbinding sections from different books. ${ }^{10}$ Each challenges B. J. McMullin's assertion that "the progress of perfected sheets from printer's warehouse to reader's hand via binder's shop was doubtless in most instances straightforward." ${ }^{11}$ Although the evidence of modern rare book collections might support McMullin's claim, their propensity for selecting only the best preserved, complete, and more attractive copies of books suggests the surviving witnesses are biased, favoring those copies where the process was unproblematic. ${ }^{12}$ While McMullin is no

8. Vincent Alsop, Anti-Sozzo, sive, Sherlocismus Enervatus: in Vindication of Some Great Trutbs Opposed (London: for Nathaniel Ponder, 1675), A2v".

9. For a fuller discussion of the various elements that bookbinders might be expected to bring together in a volume, see Mirjam M. Foot, Bookbinders at Work: Their Roles and Methods (London: British Library, 2006), 7.

10. William Blades, The Enemies of Books, 2nd ed. (London: Elliot Stock, 1888), $103-4$.

11. McMullin, "Printers' Instructions," 78.

12. Jeffrey Todd Knight, Bound to Read: Compilations, Collections and the Making of Renaissance Literature (Philadelphia: University of Pennsylvania Press, 2013), 2684. Knight shows how later bindings have disrupted earlier practice, but he attributes agency more to owners than bookbinders, who become the silent enactors of the formers' decisions. 
doubt right to assert that more books successfully navigated the bookbinding process than failed to do so, this article nevertheless investigates moments where the process was not "straightforward." In particular, it examines instances both where bookbinders deliberately took steps to complicate and obstruct the process of turning loose sheets into books, and those where, even where they were willing to bind books, the process proved problematic. Exploration of both discourses and facts surrounding these exceptions sheds light on the book trade, the processes of production, and the position of and attitudes towards bookbinders in early modern England. Such a study is of value because it illuminates an aspect of the early modern book trade that has often been overlooked.

Alexandra Gillespie has recently commented that "Bookbindings often seem to be the very last thing of interest to book historians," and a number of recent works that elide the bookbinding process testify to this. ${ }^{13}$ These narratives implicitly endorse McMullin's argument that bookbinding merits little attention, while other studies denigrate the abilities of bookbinders. Robert J. D. Harding's claim that some midsixteenth-century luxury bindings show "an intellectual concept of the codex and a creative input beyond the competence of the average, often semi-literate, bookbinder" is perhaps an extreme example of denying agency to the bookbinders. ${ }^{14}$ But other studies, such as those on sammelbände where discussion of bookbinders might be expected, prioritize readers and owners at the expense of those who completed the work. ${ }^{15}$

13. Alexandra Gillespie, "Bookbinding and Early Printing in England," in $A$ Companion to the Early Printed Book in Britain 1476-1558, ed. Vincent Gillespie and Susan Powell (Cambridge: D. S. Brewer, 2014), 93. Seminal works which largely ignore bookbinders include: Adrian Johns, The Nature of the Book: Print and Knowledge in the Making (Chicago: Chicago University Press, 1998); Hackel, Reading Material; Andrew Pettegree, The Book in the Renaissance (New Haven: Yale University Press, 2011).

14. Robert J. D. Harding, "Authorial and Editorial Influence on Luxury Bookbinding Styles in Sixteenth-Century England," in Tudor Books and Readers: Materiality and the Construction of Meaning, ed. John N. King (Cambridge: Cambridge University Press, 2010), 125.

15. Alexandra Gillespie, "Poets, Printers and Early English Sammelbände," Huntington Library Quarterly 67 (2004): 189-214; Christopher D'Addario, "Echo Chambers and Paper Memorials: Mid and Late-Seventeenth-Century Book-bindings and the Practices of Early Modern Reading," Textual Cultures 7, no. 2 (2012): 7397. For an interesting discussion of how a bookbinder might decide to bind books 
At the other end of the spectrum are those studies that celebrate bookbinders' abilities and achievements, particularly when discussing fine bindings. These studies often present the process as unproblematic, as do many investigations of the lower end of the market where the mechanics of binding or binding styles are discussed rather than the bookbinders themselves, whose agency sometimes disappears. ${ }^{16}$

Even where bookbinders and bookbinding have been a focus of greater study, three narratives have often been promoted that have downplayed the awkwardness that bookbinding might entail. The first, articulated by commentators such as Lucien Febvre and Henri-Jean Martin and corroborated by bibliographers, is that bookbinders were poor. ${ }^{17}$ This had two consequences: scholarly consensus that wherever possible bookbinders were keen to take on jobs, and that they diversified out of bookbinding into other work at every opportunity. Their aim was to find ever cheaper

together to create a new product see András Kiséry, "An Author and a Bookshop: Publishing Marlowe's Remains at the Black Bear," Philological Quarterly 91 (2012): 375 .

16. For decorated bindings see Paul Needham, Twelve Centuries of Bookbindings 400-1600 (New York: Pierpoint Morgan Library, 1979); Anthony Hobson, Humanists and Bookbinders (Cambridge: Cambridge University Press, 1989); H. M. Dixon and M. M. Foot, The History of Decorated Bookbinding in England (Oxford: Clarendon Press, 1992); Mirjam Foot, The Decorated Bindings in Marsh's Library, Dublin (Aldershot: Ashgate, 2004); Stuart Bennett, Trade Bookbinding in the British Isles, 1660-1800 (New Castle, DE, and London: British Library, 2004); David Foxon, "Stitched Books," The Book Collector 24 (1975): 111-24; Aaron T. Pratt, "Stabstitching and the Status of Early English Playbooks as Literature," The Library, 7th ser. 16, no. 3 (2015): 304-28; Nicholas Pickwoad, "Tacketed Bindings: A Hundred Years of European Bookbinding," in "For the Love of the Binding": Studies in Bookbinding History Presented to Mirjam Foot (London: British Library, 2000) 119-68; David Pearson, English Bookbinding Styles 1450-1800, A Handbook (London: British Library and Oak Knoll, 2005). Recent guides to the early modern book concentrate on binding processes and do not suggest that it was problematic: Mark Bland, A Guide to Early Printed Books and Manuscripts (Chichester: Wiley-Blackwell, 2010), 75-82; Joseph A. Dane, What is a Book?: The Study of Early Printed Books (Notre Dame, IN: University of Notre Dame Press, 2012), 143-56.

17. Lucien Febvre and Henri-Jean Martin, The Coming of the Book: The Impact of Printing 1450-1800, ed. Geoffrey Nowell-Smith and David Wootton, trans. David Gerard (London: Verso, 1990), 104-8. For the poverty of bookbinders see David Pearson, Oxford Bookbinding 1500-1640 (Oxford: Oxford Bibliographical Society, 2000), 118. 
and quicker methods of going about their activities. ${ }^{18}$ The second dominant narrative is that bookbinders lacked influence, particularly in the Stationers' Company, which from the 155 os regulated the book trade. ${ }^{19}$ The third is that the Stationers' Company and successive governments were not interested in bookbinders, even when through their involvement in illicit books or sub-standard practices they transgressed. ${ }^{20} \mathrm{My}$ aim here is to refine these narratives by drawing attention to some instances where despite, or indeed because of, their poverty bookbinders did take action sometimes to prevent book production. I also demonstrate that although governments did not necessarily punish bookbinders severely, the threat of punishment and fear of reprisal did, sometimes, make bookbinders take action to suppress texts. What will emerge is a sense of their agency, especially to hinder book production, as perceived both by their actions and the discourses around them.

The counter-intuitive notion that bookbinders sometimes obstructed book production needs some consideration, not least because it is problematic. Aside from the inherent bias of surviving collections, the terms "'Bookbinder', 'bookseller' and 'stationer," as David Pearson has commented, were used "apparently interchangeably" in the early modern period. ${ }^{21}$ Assessing the negative impact of these key members of the book trade frequently involves trying to establish that they did not do things, rather than showing that they did. It must rely, in some instances, not on physical objects but written and printed texts. Finally, since many books were sold unbound, and bindings were negotiated with individual purchasers on a case-by-case basis, it might seem unlikely that bookbinders could influence anything other than a few individual copies. As we shall see, however, the influence of bookbinders extended beyond

18. Nicholas Pickwoad, "Onward and Downward: How Binders Coped with the Printing Press before 1800," in A Millennium of the Book, ed. Robin Myers and Michael Harris (Winchester: St. Paul's Bibliographies, 1994), 61-106; Bennett, Trade Bookbinding, 27-54.

19. Cyprian Blagden, The Stationers' Company (London: George Allen and Unwin, 1960), 39; Peter W. M. Blayney, The Stationers' Company and the Printers of London, 1501-1557, 2 vols. (Cambridge: Cambridge University Press, 2013).

20. David Loades, Press Censorship and the Reformation (London: Pinter Publishers, 1991), 112; Maureen Bell, "Elizabeth Calvert and the 'Confederates,'” Publishing History 32 (1992): 27.

21. Pearson, Oxford Bookbinding, 118. 
individual items to multiple copies, and sometimes whole editions, either deliberately or inadvertently. Examining these interventions helps us understand the pressures bookbinders worked under and their priorities. It offers us insights into the workings of the book trade and reminds us that every surviving stitched or bound text from the early modern period has negotiated a complex and sometimes awkward process of binding.

The difficulty of that process is evidenced by bookbinders' agitation in the early modern period. Collectively, they complained about or sought changes in things as diverse as the importation and prices of bound books, the numbers of apprentices each master could have, equitable distribution of work, and whether membership of the Stationers' Company should be a prerequisite to trading. ${ }^{22}$ Three other issues, in particular, concerned them: quality control, the granting of patents, and censorship. Each reveals a different aspect of the complex relationship bookbinders had with their customers, the government, and with the Stationers' Company, the last of which both represented and regulated them and of which some bookbinders, but not all, were members. The topics also bring to the fore the double-facing nature of the bookbinders who worked with and for booksellers, binding books prior to sale on a wholesale basis, as well as taking commissions in the retail trade from individual customers who wanted bespoke bindings. Whether acting individually or collectively, bookbinders sought to exploit their position as essential agents of textual production to improve their lot. They had varying degrees of success, and their struggles led them to be perceived in some quarters as difficult to

22. For the 1534 Act that legislated on bound books brought into England from overseas, see Blayney, Stationers' Company, 1:330-39; for all the other issues emanating either from the 1578 petition considered by the Court of the Stationers' Company or the 1612 order pertaining to apprentices, see Blagden, Stationers' Company, 64-65 and 113. For discussions on pricing, see Mirjam Foot, "Some Bookbinders' Price Lists of the Seventeenth and Eighteenth Centuries," in Economics of the British Booktrade 1605-1939, ed. Robin Myers and Michael Harris (Cambridge, Alexandria, VA: Chadwyck-Healey 1985), 124-75; Bennett, Trade Bookbinding, 11-54; Penelope Morgan, "An Unrecorded Seventeenth-Century Hereford Bookbinder," The Library, 6th ser., no. 10 (1988): 145-50. For examples of the ways in which bookbinders exerted their agency in relation to prices on an individual basis, see the complaint of Joseph Mede, in David McKitterick, "Customer, Reader and Bookbinder: Buying a Bible in 1630," The Book Collector 40 (1991): 382-406; and John Dunton, The Dublin Scuffle Being a Challenge Sent by Jobn Dunton, Citizen of London, to Patrick Campbell, Bookseller in Dublin (London, 1699), $3 \mathrm{D}_{4}^{\mathrm{v}}-5^{\mathrm{r}}$. 


\section{Deceit, Self-Interest, and Censorship}

deal with, unreliable, and deceitful. What also emerges is their anxiety about involvement in the production of illicit texts and the difficulties that financial pressure created.

From the mid-sixteenth century, bookbinders were regulated by the Stationers' Company, which received its royal charter in 1557 and oversaw issues such as quality, prices, apprenticeships, and licensing of copyright. ${ }^{23}$ Governments also regulated aspects of the book trade by the Star Chamber decrees of 1566,1586 , and 1637 , sets of ordinances in 1643 and 1678 (supplemented in 1681 and 1683), and acts of Parliament in 1649, 1653, and 1662. Alongside these regulations, royal proclamations and patents were issued, often in response to specific issues or at the behest of individuals. ${ }^{24}$ Sometimes these challenged the Stationers' Company's authority. Responsibility for regulation of the trade lay with the Company, but both the Company and governments employed searchers to help ensure compliance. Censorship of texts and ownership of copyright were managed by a licensing system whereby books could be (but did not have to be) recorded in the Stationer's Register, and by post-publication recalling of texts. ${ }^{25}$ Inevitably, given the political upheavals of the sixteenth and seventeenth centuries, the degree to which regulation of the book trade was effectively monitored varied enormously. Cyndia Susan Clegg has suggested that Jacobean preprint press control achieved a higher rate of conformity than did Elizabethan arrangements, especially in the 1620 s. She notes that 1623 and 1624 were years of particular suppression and, as we shall see, 1625 pro-

23. This summary draws on Blagden, Stationers' Company, $145^{-52}$ and Johns, $\mathrm{Na-}$ ture of the Book, 230-34, who I follow closely.

24. For proclamations relating to press censorship see Paul L. Hughes and James F. Larkin, eds., Tudor Royal Proclamations, 3 vols. (New Haven: Yale University Press, 1969), 1:181, 193, 270, 341, 373, 387, 393, 432, 478, 481, 484-85, 514; 2:5, 41, 91, 93, 103, 115, 312, 341, 347, 375, 376, 400, 445, 501, 506, 534; 3:34; James F. Larkin and Paul L. Hughes, eds., Stuart Royal Proclamations, 2 vols. (Oxford: Clarendon Press: 1983), 1:74, 211, 243, 295, 355, 393, 495, 519, 583, 599; 2:8, 93, 197, 218, 506, 510, 557. For patents, see Arnold Hunt, "Book Trade Patents 1603-1640," in The Book Trade and Its Customers 1450-1900, ed. Arnold Hunt, Giles Mandelbrote, and Alison Shell (Winchester: St. Paul's Bibliographers, 1997), 27-54.

25. For a comprehensive explanation of press control in the Elizabethan and early Stuart periods, see the three books by Cyndia Susan Clegg: Press Censorship in Elizabethan England (Cambridge: Cambridge University Press, 1997); Press Censorship in Jacobean England (Cambridge: Cambridge University Press, 2001); Press Censorship in Caroline England (Cambridge: Cambridge University Press, 2008). 
vides rare evidence of a bookbinder seeking to suppress a text in a period of significant anxiety. ${ }^{26}$ The fall of the Star Chamber in ${ }_{1641}$ led to looser press controls, but they were tightened under Cromwell. ${ }^{27}$ The collapse of that regime again brought instability, and Charles II sought to restore order through the 1662 Press Act and the appointment of Roger L'Estrange as Surveyor of the Press. ${ }^{28}$ This became a government post in 1663 , and "throughout the late seventeenth century he sought ways to prosecute the producers of what he considered to be seditious publications." 29 His role was complicated by the lapsing of the Press Act in 1679, its renewal in 1685 , and its lapsing again ten years later. ${ }^{30}$ Against this background of sometimes intense, sometimes lax regulation the bookbinders plied their trade. Positioned in the middle between authors and readers, and working with, for, and sometimes against booksellers and the Stationers' Company, their compliance, though frequent, could not be guaranteed.

\section{BINDING QUALITY}

The much-cited regulations regarding binding quality were articulated in an ordinance of ca. 1562, supplemented by the Star Chamber Decree of $1586 .{ }^{31}$ They set out expectations about binding and stitching, and Arber's transcript of the Stationers' Company records shows that there was a small flurry of prosecutions in $155^{8-59}$ and $1563-65 .{ }^{32}$ James Robotham was fined two shillings and six pence for "that he bounde ii hundreth of premers in skabertes which [is] contrary to [the] orders of this howse," "arthure pepwell" was fined ios. "for that he bound bookes in skabertes," and "ffraunces goodlyf" paid 4s. "for his fine that he bounde premers in parchmente / and also for that he bounde them unJustely and

26. Clegg, Jacobean England, $5^{8}$.

27. Johns, Nature of the Book, 231.

28. Peter Hinds, "The Horrid Popish Plot": Roger L'Estrange and the Circulation of Political Discourse in Late Seventeenth-Century London (London: Oxford University Press for the British Academy, 2010), 36.

29. Ibid., 36-37.

30. Johns, Nature of the Book, 231-34.

31. Blagden, Stationers' Company, 45.

32. Edward Arber, ed., A Transcript of the Registers of the Company of Stationers of London 1554-1640, 5 vols. (London and Birmingham: Privately printed, 1875-94), 1:100, 239 . 
contrary to the order of this howse." ${ }^{33}$ It is difficult to ascertain whether the lack of punishments meant general compliance with the orders or a failure to prosecute, but it is clear that a few bookbinders tried their luck. ${ }^{34}$

There appear to be no fines immediately following the 1586 decree, and in the seventeenth century prosecutions for such misdemeanors were few and far between. In 1625 a fine was imposed on William Garret for using "unfitting Wordes" to a searcher sent by the Company who was looking for books bound in sheepskin. ${ }^{35}$ Sheepskin being of less good quality and cheaper than other materials it was potentially attractive to bookbinders as an alternative to calfskin. Bookbinders were sufficiently interested in the material to petition Archbishop Laud, to establish "what books are to be bound in sheep." ${ }^{36}$ In 1646, a complaint about binding quality emerged when Daniel Frere complained against a bookbinder named Watkins "for deceitful binding," but no details of the outcome of this complaint remain. ${ }^{37}$ Deceitfulness seems to have been an on-going problem. Five years later, the government issued a warning entitled To Undeceive the People of this Common-Wealth (1652), about falsely bound Bibles. The single-sided broadside noted that the Bibles were "bound most basely in Mutton Taffety ... in plaine Termes, in Sheeps Leather, both Black and Red, under the name of Spanish Leather and others." It went on to note that many Bibles were "guilded with Party Gold, and not headbanded, nor truly sowed on Slips, but on Packthread, and five Sawes in the back, and but three slips to the said sawings." They concluded that such Bibles "cannot last to doe good service." ${ }^{38}$ The attention to detail on binding is remarkable. Not only does the warning claim that sheepskin is being passed off as good quality Spanish leather, but it notes that the quality of the gilding is defective,

33. Ibid., 1:239, 274.

34. In "Stitched Books," Foxon tries to establish "how far the Stationers' order was followed" (112), but he only looks at thirty-two books from the Bodleian Library, and his conclusion is somewhat hedged.

35. William A. Jackson, ed., Records of the Court of the Stationers Company 16021640 (London: Bibliographical Society, 1957), 176.

36. Blagden, Stationers' Company, 114.

37. D. F. McKenzie and Maureen Bell, eds., A Chronology and Calendar of Documents Relating to the London Book Trade 1641-170o, 3 vols. (Oxford: Oxford University Press, 2005), 1:184.

38. To Undeceive the People of this Common-Wealth (London, 1652). 
while the headband, located at the top of the binding for strength and decorative purposes, is wanting. The stitching, construction, and materials are all described as substandard, especially for a book expected to receive a considerable amount of use, such as the Bible. ${ }^{39}$ The warning concludes by observing that the Bibles were sold "at two shillings a Book bound, or rather under," and that this very cheap price made the Bibles obvious; an early version of you get what you pay for. ${ }^{40}$

It is perhaps items like this that led to the association of binders with deception and trickery. John Dunton, himself a member of the book trade, picked up the theme in his An Hue and Cry after Conscience: or the Pilgrim's Progress by Candlelight (1685). Mimicking the style of John Bunyan's Pilgrim's Progress, the second part of which had come out the year before, Dunton's work reflects on the economic conditions of the times. In it the pilgrim, named "Discovery," finds "All manner of Vice and Roguery" while looking for "Honesty" and "Plain-dealing." ${ }^{41}$ Meeting a bookbinder, Discovery is told that "Honesty" and "Plain-dealing" frequented the street twenty years ago, but could barely earn enough to pay the rent. The bookbinder claims to have "sham'd 'em off with sham Turkey, Sheep-skin for Calf, Scabards instead of Past-board, Glew without sowing, and the like." ${ }^{42}$ Dunton highlights many of the same practices complained about in the 1651 warning. "Turkey" was the highest quality leather, made from tanned goatskin, and often imported from Turkey but here fraudulently imitated; sheepskin is made to look like the more expensive calfskin, and very thin wooden boards deployed in the cheapest bindings ("Scabards") are used instead of the higher quality pasteboards, made by pasting paper together. ${ }^{43}$ Finally, glue is

39. Books bound using the method of sawing grooves into the back of the book and placing cord in them onto which the sections of the book were sewn produced a weaker binding than one where sections of the book were sewn on to raised bands or cords with the stitching going round each band. See Geoffrey Ashall Glaister, Glossary of the Book (London: George Allen and Unwin, 1960), s.v. "flexible binding" and "sawn-in back."

40. To Undeceive the People.

41. John Dunton, "The Bookseller to the Reader," in An Hue and Cry after Conscience: or the Pilgrim's Progress by Candlelight (London: for John Dunton, 1685), $\pi 2^{r-v}$.

42. Ibid., $\mathrm{B} 7^{\mathrm{r}}$.

43. These definitions of Turkey leather, "scabard," and pasteboard are drawn from Pearson, Bookbinding Styles, 19, 22. 
used rather than sewing, meaning that the binding is much weaker. Though Dunton mocks Bunyan's style, there is a serious point beneath the humor. Elsewhere in his writing, Dunton commented positively on many of the bookbinders of his day, and his decision to make a bookbinder the friend of "Knavery" from whom the former claims to have received much money is both a commentary on the bookbinding trade, society more widely, and the impact of poverty. ${ }^{44}$ Dunton's narrative adds a literary gloss to the earlier warning that reflected on practice. In both fact and fiction, the fraudulence of bookbinders was brought to the fore. Challenging the Stationers' Company's instructions and regulations, bookbinders were presented as seeking to deceive customers and supply substandard work. A similar lack of compliance also emerges in relation to the vexed question of patents.

\section{PATENTS}

If the discourse around the quality of bookbinding suggests that some sections of the trade engaged in fraudulent practice, it is nevertheless true that bookbinders were, in those cases, still trying to get books bound and sold. The evidence relating to patents is more ambiguous and shows the bookbinders seeking to prevent the implementation of decrees relating to bookbinding. It also shows them at the mercy of the booksellers, who had greater representation in the Stationers' Company, and at times refusing to take binding jobs. ${ }^{45}$ As we shall see, however, this apparent refusal of business was motivated by a desire to gain better business opportunities.

Arnold Hunt identified seventy patents covering the book trade in the period $1603-40$, and of these, seven relate to bookbinding. Two were reversions for the post of King's Bookbinder, but the others pertained more specifically to the binding of books. Adrian Johns has told the wider story of how patents were challenged by such figures as Michael Sparke and William Prynne, but here I want to focus specifically on the issues relating to bookbinding. ${ }^{46}$ Although George Wither's patent has received significant critical attention, the others have been largely neglected, and taking them together facilitates a clearer understanding

44. John Dunton, Life and Errors of John Dunton (London: for S. Malthus, 1705), $\mathrm{X}^{\mathrm{v}}-2^{\mathrm{r}}, \mathrm{Z}_{2}^{\mathrm{v}}-4^{\mathrm{v}}$.

45. Blagden, Stationers' Company, 39.

46. Johns, Nature of the Book, 326-38. 


\section{Bibliographical Society of America}

of the bookbinders' position in the market and the way their concerns were presented.

It was not unknown for the Stationers' Company to receive instructions from outside agencies, and occasionally these related to binding. On 3 October 1615, following a requirement of the archbishop of Canterbury, instruction was given by the Company for the Bible to be bound up with copies of the Apocrypha:

publique notice [was] given by the table [i.e. the Court] to many of the Company that were $\mathrm{p}[\mathrm{rese}] \mathrm{nte}$, according to my Lorde of Canterbury his Graces direction that no more bibles be bounde up and sold $\mathrm{w}^{\text {th }}$ out the Apocripha in them upon paine of one whole yeares Imprisonment. ${ }^{47}$

It was followed up by a command a few months later that all copies of the Bible without the Apocrypha be "deliv[er]ed to mr Phillip Kinge." 48 The quite severe punishment and the subsequent action suggest the authorities' concern with the Bible, and Jackson has contextualized this decree as an attempt to prevent the spread of Puritan annotation of the Bible. ${ }^{49}$ Whether this directive met with resistance from the bookbinders is unclear, but very shortly afterwards a similar patent created problems in relation to bookbinding.

In October 1610 John Speed had obtained a patent to print The Genealogies of the Holy Scripture and the map of Canaan and to have them bound with every copy of the new translation of the Bible for the next ten years. ${ }^{50}$ The patent also dictated the amount Speed would be paid by the Company for each copy. It seems possible that the Stationers' Company was half-hearted in implementing the decree because, five years later, it was using its ability to enforce the patent as a means to renegotiate the rates of pay. On 21 November 1615, the Court agreed to use and Imploy their best meanes and indeavo[u $]^{\text {rs }}$ that no bibles of what volumes or translac[i]on soev'[er] shall dureing the said terme of the said Indenture be bound up or uttered unles one of the said Genealogies and Mappes be inserted and bounde in the said bible. ${ }^{51}$

47. Jackson, Records, 77 .

48. Ibid., 99.

49. Ibid., 206.

50. Hunt, "Book Trade Patents," 43.

51. Jackson, Records, 78 
By promising to enforce the patent and get the Genealogies and map bound with the Bible, the Court managed to reduce the rate from lod. to $8 \mathrm{~d}$. per copy for quarto copies of the book. In 1617 and in 1623 the patent was renewed, this time for seven years on each occasion, but by the mid-163os when Speed's son, also John, was the beneficiary, problems recurred. ${ }^{52}$

In April 1634, the younger John Speed petitioned the Privy Council to enforce the patent. His petition reveals that there had been, at an unknown point, a counter-order prohibiting the annexation of the Genealogies with the Bible. In January 1634 this ruling had itself been overturned, but the booksellers, on the pretext that the books were already bound, were not complying with the reinstatement:

The Board on the last of January ordered the Company of Stationers, that notwithstanding a former order prohibiting the annexing the genealogies with the Bibles, they should proceed according to a patent in that behalf till they had further order. Though their pleasure was by the Master, Wardens, and assistants generally received with alacrity to perform it, yet the multitude of booksellers refuse to be governed by the said message, the Bibles being as they pretend before bound up, and have returned the genealogies, and since the message have dispersed many thousands of books without them, to the loss of petitioner. ${ }^{53}$

The language here is noticeable. While "pretend" in the early modern period does not have to imply an element of deception but rather "advocated" or "put forward for consideration," such a nuance was available, and the innuendo of untruthfulness on the part of the booksellers suits Speed's argument. What is also striking is Speed's, perhaps exaggerated, claim that "many thousands" had been bound prior to retail sale, which suggests either defiance of the original order on an extensive scale or massive and fairly rapid compliance with it. Whatever the circumstances under which copies of the Bible were bound up without the Genealogies, it is clear that there was resistance to the reinstatement of the original patent. Whether that was the booksellers' or bookbinders' initiative, the case shows that it was the binding of the book which problematized its coming to market. With many copies now bound there was an unwill-

52. Hunt, "Book Trade Patents," 45.

53. John Bruce, ed., Calendar of State Papers Domestic, Charles I, 1633-1634 (London: Longman, Green, Longman, Roberts, and Green, 1863), 576-77. 
ingness to incur the costs of unbinding and then rebinding the two books in one volume. Ultimately, the resistance seems to have worked to the Company's advantage. Although Speed renewed the patent in 1637, he sold it a year later to the Company for $£_{700}$, and they gave him an additional $£ 10$ for "his loveing Conclusion" of the matter. ${ }^{54}$

If the Speeds' patent was contentious, it was as nothing compared with the furor surrounding that granted to George Wither. As Norman Carlson has explained, Wither had been granted a patent to have his The Hymns and Songs of the Church bound up and sold with all copies of the Psalms in Metre, the rights to which were lucrative and belonged to the Company. Carlson comments, "in the following ten years at least fifty-nine separate editions, or about 87,000 copies, of the metrical psalms were to be printed." ${ }^{55}$ Wither was also granted the right to search printers' or booksellers' properties to find and seize copies of Psalms in Metre that did not have The Hymns and Songs bound with them. Wither's monopoly caused consternation, and the Company refused to enforce it. In 1624, the bookbinders petitioned Parliament against the patent, for although larger books cost more to bind and brought in more income, the bookbinders claimed that the higher price of the book would actually reduce sales. ${ }^{56}$ They presumably also saw the opportunity of having two books to bind separately a more lucrative proposition than one larger book. In addition, the bookbinders disliked the authority Wither had to search their properties and the actions the booksellers were taking to evade the patent, at the expense of the London bookbinders. As Allan Pritchard has observed, the booksellers "adopted the practice of sending books 'in quires' to the country for binding, in order to evade attempts at enforcement of the offensive clause." ${ }^{57}$ The bookbinders' collective agency helped drive opposition, but their own situation was compromised. Nor, in the short term, were the bookbinders' successful, for in 1624 Wither took his case to the Privy Council and won. Despite this, further resis-

54. Jackson, Records, 317.

55. Norman E. Carlson, "Wither and the Stationers," Studies in Bibliography 19 (1966): 211.

56. R. Lemon, Catalogue of A Collection of Printed Broadsides in the Possession of the Society of Antiquaries of London (London: Society of Antiquaries, 1866), 65, cited in Jackson, Records, 156.

57. Allan Pritchard, "George Wither's Quarrel with the Stationers: An Anonymous Reply to The Schollers Purgatory," Studies in Bibliography 16 (1963): 29. 
tance clearly ensued, because he was back again in 1627 and 1634 taking out further injunctions to enforce the patent. At the last event he claimed to have $£_{5} 00$ of books (perhaps $4,000-5,000$ copies) still unsold, perhaps reflecting the effectiveness of the bookbinders' actions even if their petitions had failed. ${ }^{58}$ Moreover, on this occasion he lost, with the Stationers' Company's rights upheld and "that part of the grant which directed the hymns and psalter should be bound together" being revoked. ${ }^{59}$ Persistent obstruction in practice and vocal opposition at law had enabled the Stationers' Company and the bookbinders to overthrow the detested patent. Their refusal to bind the books as directed was apparently an example of the refusal of an opportunity to make money but emerged in part from the belief that more money could be made from binding the work in other ways.

Wither's case is insightful when we consider the agency of the bookbinders. Acting collectively, and both with and against the Stationers' Company whose members also sought to exploit the situation of the London bookbinders, the latter were ultimately able to get a patent repealed that they saw as working against their interests. At first glance it appears as though the bookbinders were foregoing business opportunities in rejecting the patent's opportunity to increase charges and undertake binding work, but they saw a potentially larger market, and theirs was not the only issue at stake. The Company's interests in the Psalter were also compromised by Wither's patent, and this drove the obstructionist practice and appeals to Parliament. Taken together, the disputes with the Speeds and with Wither show that, on particular issues, the bookbinders might obstruct the production of texts. However, this was often part of a bigger picture in which lucrative patents owned by the Stationers' Company were at issue rather than merely the bookbinders' interests.

Only one other patent for binding of books exists for the period 160340 , and it suggests that with these ongoing rows about Wither's and Speed's works, the petitioner was more cautious. The documents suggest too, that the bookbinders were once again trying their luck, with perhaps a more traditional practice. On 1 December 1628, on the authority of the bishop of London, the master and wardens of the Stationers' Company,

58. Carlson, "Wither and the Stationers," 213.

59. Marjorie Plant, The English Book-Trade, 3rd ed. (London: George Allen and Unwin, 1974), 111. 
gave warning to the Bynders not to bynde the bible $\mathrm{w}^{\text {th }}$ the doctrine of Bible the history of the Bible or any other booke other then the Comon prayer the Psalmes, the geneologies as are allowed $\mathrm{w}^{\text {th }}$ authoritye to be bound therewith. ${ }^{60}$

Their decree reveals that in addition to Speed's Genealogies, both the Book of Common Prayer and the Psalter could be bound with the Bible. It also hints at bookbinders trying to add to the Bible books that were not permitted. The extent to which this practice continued is hard to judge, but in March 1630 it seems it was still happening. Clement Cotton referred to it when he sought an amendment to his patent for the printing of $A$ Brief Concordance to the Bible of the last Translation (1630) that he had obtained in 1629, and which must have included a requirement for it also to be bound with the Bible. An ill wife and financial necessity meant he had sold on the patent, but the clause about binding the book with the Bible seems to have run into difficulty. By March 1630 the Privy Council had "constrained the binding of the Concordance with the Bibles," and Cotton's petition now was to ask that those who wanted to buy the two items together might be allowed to do so. ${ }^{61} \mathrm{He}$ did not contest the Privy Council's prohibition against the forced binding of the two works together.

At the same time that he wrote to the Privy Council, Cotton also addressed Archbishop Laud. His letter picks up on, perhaps deliberately echoes, the 1628 decree in its assertion that "two small treatises of the History and Doctrine of the Bible have been bound up with the Bible to the prejudice of [his] grant as to the Concordance." ${ }^{62}$ Cotton sought the insertion into his patent of a clause that meant that "books[,] unless they have the allowance expressed in the said clause are to be prevented"

6o. Jackson, Records, 206.

61. John Bruce, ed., Calendar of State Papers, Domestic, Charles I 1629-1631 (London: Longman, Green, Longman, and Roberts, 1860), 208.

62. Ibid. The works referred to are probably STC 19108-19109 (Eusebius Paget, The History of the Bible, Briefly Collected by way of Question and Answer [London, J. L[egat], 1627, 1628]), and, according to STC, either STC 3030.5 or STC 25132. The former was a 1625 edition of The Doctrine of the Bible: or, Rules of Discipline (London: E. Allde for T. Pavier, 1602), published in duodecimo but also published as an octavo under the title, The Way to True Happiness Leading to the Gate of Knowledge. By Questions and Answers (London: [W. Jaggard] for T. Pavier, 1602). An edition of this second work was authorized in 1626 and perhaps came out in 1630 (STC 25136). 
from being bound with the Bible. He seems to have been successful, because the patent as written covers all eventualities. It noted, "no other concordance may be bound with the Bible without special authority from the Archbishops of Canterbury and York and the Bishop of London, or any two of them, or under the Great Seal." It also stated that no one was to be "constreyned to buy the saide concordance togeather with the Bible, but . . . with or without the said concordance as themselves shall please." ${ }^{63}$ Decisions about whether to have the concordance bound with the Bible or not were to be left with the customers, but if they did decide to have the concordance bound up with the Bible, then it had to be Cotton's version.

The Company's decree of December 1628, along with Cotton's plea, suggest that bookbinders were continuing to engage in some opportunism, though of course such a narrative also aided Cotton's petition. On this occasion, the bookbinders were adding illicit items to the Bible rather than preventing texts being sold with it, but the contention surrounding it shows the importance of being able to bind as well as print texts. The overall effect of Cotton's patent was that it became in effect a selling point for the concordance. In an unusual variation on the standard statement about authorization of printed texts, the concordance advertised that it was "Allowed by Authoritie to be printed" and "bound with the Bible in all Volumes." ${ }^{4}$ The flexibility of this patent elicited no recorded complaint from the bookbinders, although as Hunt notes, $\mathrm{Mi}$ chael Sparke objected to it in his Scintilla (1641) because of the abuse made of the privilege whereby cheaper concordances printed overseas were seized and then sold on at a higher price. ${ }^{65}$

These three patents show the importance of being able to bind texts with the Bible, one of the period's bestselling books. They reveal too that bookbinding was the concern not only of bookbinders but also of the Stationers' Company and booksellers, particularly when the Company's own patents or popular works were at issue. The bookbinders were able to put forward their own case, acting collectively, but were also in

63. Hunt, "Book Trade Patents," 51.

64. The $S T C$ makes clear that Cotton obtained the patent for printing in 1629 and assigned it on (John Downame, A Brief Concordance to the Bible of the Last Translation [London, 1630], title page).

65. Hunt, "Book Trade Patents," 51, citing Michael Sparke, Scintilla (London, 1641), $\mathrm{A}_{4}^{\mathrm{r}}$. 
danger of being split as a group by the booksellers who, through their practice of sending books out to the country, challenged the position of the London bookbinders. The stakes were high because the patents were lucrative, because the books were bestsellers, and it is presumably this feature that the petitioners identified when seeking their patents. The bookbinders tried to circumvent them both by appealing against those patents that demanded the binding of a work with the Bible, and by availing themselves of the opportunity to bind other works with it when they chose to. Over the long term, in each case it seems that the bookbinders achieved an outcome which was satisfactory to them: Speed's patent was sold back to the Company; Wither's offending clause was overturned; and in Cotton's case, a compromise seems to have been reached. While these cases played out in the tense atmosphere of late-Jacobean and Caroline England, the earlier period also saw an unusual case of textual repression involving bookbinders. It suggests another way in which the binding process was problematic.

\section{BOOKBINDERS AND THE SUPPRESSION OF TEXTS}

To appreciate why a bookbinder in the 1620 s might have been anxious about binding texts, we need to understand the regulatory situation and the practice of book-trade control as they pertained to bookbinders. Although they have traditionally been overlooked in discussions of censorship and press control, bookbinders were covered by the regulations as early as the mid-sixteenth century and at various points in the early modern period were interrogated and punished. ${ }^{66}$ The 1566 Star Chamber decree, "for reformation of divers disorders in printing and uttering of Bookes," prevented the printing and importation of books that went against the "forme and meaning" of government statutes and decreed:

66. Many seminal works on censorship in the early modern period pay no attention to bookbinders, such as Annabel Patterson, Censorship and Interpretation: The Conditions of Writing and Reading in Early Modern England (Madison: University of Wisconsin Press, 1984); Clegg, Elizabethan England; Janet Clare, "Art Made Tongue-Tied by Authority": Elizabethan, and Jacobean Dramatic Censorship, 2nd ed. (Manchester: Manchester University Press, 1999); Clegg, Jacobean England; Andrew Hadfield, ed., Literature and Censorship in Renaissance England (Basingstoke: Palgrave Macmillan, 2001); S. Mutchow Towers, Control of Religious Printing in Early Stuart England (Woodbridge: Boydell Press, 2003); Clegg, Caroline England. 
That no person shall sell, utter, put to sale, bind stitch or sowe anie such Bookes or Copies, so printed or brought in, contrarie to the said ordinance, upon paine to forfait all such Bookes and Copies, and for every Booke. xx.s. ${ }^{67}$

Later proclamations such as that of 1573 "Ordering Destruction of Seditious Books" were less specific, demanding that "no man willingly do bring into this realm, disperse, dispose, or deliver" seditious books. ${ }^{68}$ The 1623 Proclamation against the "disorderly Printing, Uttering, and Dispersing of Bookes, Pamphlets, etc.," however, showed an explicit concern again with binding noting that:

every person that should wittingly sell, utter, put to sale, binde, stitch or sow, or wittingly cause to be solde, uttered, put to sale, bound, stitched or sowed, any Bookes or Copies whatsoever, Printed contrary to the intent and true meaning of the Ordinances or Articles aforesaid, should suffer three moneths imprisonment. ${ }^{69}$

The extended scope of the proclamation and the increased penalties suggest a desire to tighten control of the binding and issuing of illicit books.

Nor were such threats idle ones. Bookbinders' were interrogated and their properties searched. In 1581, the Privy Council required the vicechancellor of Oxford University to send them the incarcerated Rowland Jenckes, a bookbinder, on account of his involvement with "Papisticall books." ${ }^{70}$ In 1589, Henry Sharpe, who stitched a number of the Marprelate pamphlets, was, not surprisingly, interrogated about the arrangements for printing and publishing them. ${ }^{71} 1637$ saw Peter Ince, a bookbinder in York, have his "books and papers viewed," though with no incriminating evidence found. ${ }^{72}$ More systematic searching was decreed by the House of Lords committees investigating unlicensed printing in 1641 that recommended the Stationers' Company should periodically

67. Arber, Transcript, 1:322.

68. Hughes and Larkin, Tudor Royal Proclamations, 2:379.

69. Larkin and Hughes, Stuart Royal Proclamations, 1:583.

70. John Roche Dasent, ed., Acts of the Privy Council of England 1581-2 (London: HMSO, 1896), 34-35.

71. Joseph L. Black, ed., The Martin Marprelate Tracts (Cambridge: Cambridge University Press, 2008), liii.

72. John Bruce, ed., Calendar of State Papers, Domestic, Charles I, 1637 (London: Longmans, Greene, Reader, and Dyer, 1868), 492. 
search for all unlicensed books in bookbinders' and booksellers' shops. ${ }^{73}$ In addition, the authorities also required some bookbinders to deposit bonds for good behavior, and a change in government during the Commonwealth period brought little relief for those from whom books had been taken in an earlier period: William Brook was told in 1654 that he could not have back the books seized "sundry yeares since" because they were "Papist." 74 The Restoration and L'Estrange's appointment saw the continuation of inspections and intelligence gathering. ${ }^{75}$ Arguably the most notorious case was the trial of John Twyn, in which the bookbinder Nathan Brooks was also arrested and tried. ${ }^{76}$ The former was executed; the latter imprisoned, sent to the pillory, and fined. ${ }^{77}$ Like printers and authors, binders could be in the firing line, and recognizing the vital role they played in turning the unbound sheets of illicit texts into usable pamphlets and books, the authorities were certainly interested in them and keen to prevent such activity. ${ }^{78}$

Some of the cases alluded to above indicate that bookbinders were willing to take risks for the sake of their religious convictions. Even then, though, there might be problems. Henry Sharpe, who stitched 700 copies of the Marprelate tract Hay any Work for Cooper (1589), initially withheld 100 from Humphrey Newman the distributor. ${ }^{79}$ On 5 January 1647, Thomas Johnson was caught sitting in the shop of the Leveller Richard Overton's shop stitching copies of Overton's Regall Tyranny Dis-

73. McKenzie and Bell, Chronology and Calendar, 1:8.

74. Ibid., 1:269 and 1:353.

75. F. H. Blackburne Daniell, ed., Calendar of State Papers, Domestic, Charles II, 1678 (London: HMSO, 1913), 54; F. H. Blackburne Daniell and Francis Bickley, eds., Calendar of State Papers, Domestic, Charles II, July I to September 30, 1683 (London: HMSO, 1934), 240.

76. See John Twyn, An Exact Narrative of the Trial and Condemnation of John Twyn for Printing and Dispersing of a Treasonable Book with the Trials of Thomas Brewster, Bookseller, Simon Dover, Printer, Nathan Brooks, Bookbinder, for Printing, Publishing, and Uttering of Seditious, Scandalous, and Malicious Pamphlets (London: for Henry Brome, 1664).

77. McKenzie and Bell, Chronology and Calendar, 1:525.

78. For active participation of a bookbinder in the suppression of texts, see the discussion of Samuel Mearne, King's Bookbinder, in John Hetet, "The Wardens' Accounts of the Stationers' Company 1663-79," in Economics of the British Booktrade 1605-1939, ed. Robin Myers and Michael Harris (Cambridge, Alexandria, VA: Chadwyck-Healey 1985), 32-59.

79. Black, Martin Marprelate, liii. 
covered (1647). ${ }^{80}$ Thus, even when bookbinders were willing participants in the production of books, the bookbinding stage in the process constituted one in which a book or pamphlet could encounter difficulties en route to its readers. One example, from 1625 , however, suggests that fear of reprisals shaped the thinking of a bookbinder and his decision about whether, or not, to bind a text.

In the 1620 s the two naval powers of England and Holland established rival East India Companies that sought to exploit the opportunities presented by trading in Asia, in particular for the spice trade. Rivalry and suspicion were intense, and in February 1623 on the Indonesian island of Amboyna, ten English merchants were arrested and imprisoned by the Dutch on a charge of conspiring to capture the Dutch fort. ${ }^{81}$ Brutally tortured, they confessed and were executed. Since this all took place at a time when, by an agreement of 1619, the English and Dutch were supposed to be working collaboratively, uproar ensued when news of events reached London in 1624. Intense diplomatic correspondence and a flurry of pamphlets published by the two East India Companies sought to justify and excuse their actions. ${ }^{82}$ Caught up in the midst of all this was the magnum opus of Samuel Purchas, Hakluytus Posthumous or Purchas His Pilgrims (1625).

Purchas had begun the process of printing his massive work long before the events at Amboyna unfolded, and it was nearing completion in late $1624 .{ }^{83} \mathrm{He}$ was embroiled in the East India Company's business because, as Pamela Neville-Sington explains, he had been allowed access to their library of manuscripts and had printed material from their archive. On 10 January 1625 , just prior to the publication of the work, he visited the East India Company. He wanted to include a dedication to the merchants, and they enthusiastically agreed. However, they wanted

8o. McKenzie and Bell, Chronology and Calendar, 1:197.

81. For this episode see John Keay, The Honourable Company: A History of the English East India Company (London: HarperCollins, 1991), 47-51.

82. For a convenient recent summary see Alison Games, "Violence on the Fringes: The Virginia (1622) and Amboyna (1623) Massacres," History 99 (2014), 505-29, especially $517-18$.

83. I draw in this paragraph on P. A. Neville-Sington, "Purchas his Pilgrimes (1625)," in The Purchas Handbook, 2 vols., ed. L.E. Pennington (London: Hakluyt Society, 1997), 2:519-37. Neville-Sington gives a full account of the printing and publishing of the work, explaining its complexities. 


\section{Bibliographical Society of America}

to make some "additions and alterations." ${ }^{84}$ In particular, they sought to comment on "the generall injuries of the Dutch [toward the English] in the Indies." ${ }^{85}$ Purchas accepted, perhaps encouraged by the £100 that they had given him. Some days later, the compiler returned. Grateful for the Company's largesse, he regretted that he could not persuade the printer to publish the revised dedication, "notwithstanding it is allowed by authority," and so the Company overcame the printer's scruples by giving him "somewhat . . to insert it." ${ }^{86}$ Purchas accordingly took his work to the bookbinder. Here too he was to encounter problems. He reported to the Company that the bookbinder had "taken advise" and been told that the epistle "may be dangerous." ${ }^{87} \mathrm{He}$ refused to include it. No doubt exasperated, the merchants pragmatically resolved to "lett it rest for a while, and if they cannot procure it to be bound with the booke, they will print it upon some other occasions." ${ }^{88}$ As copies of the work show, they could not procure it to be "bound with the booke," nor does it appear to have been published separately.

There is much that is intriguing and troubling about this episode, not least the Company's expectation of being able to publish the text at another time. However, given the increased attention on licensing in the early 1620 identified by Clegg, the heightened political atmosphere relating to the Dutch government, and tension between the two East India Companies, it is quite possible that a bookbinder might have feared reprisals for binding material considered inflammatory. If Purchas really did receive this advice and follow it, then it seems reasonable to regard the bookbinder as an agent of censorship. It is also possible that Purchas himself was anxious about the changes, but Neville-Sington's suggestion that it was he (or Stansby [the printer]) "who decided to censure the epistle," though possible, would perhaps have been a high-risk strategy. ${ }^{89}$ The Company to which he was much indebted had already bribed

84. W. Noel Sainsbury, ed., Calendar of State Papers, Colonial Series, East Indies, China and Persia 1625-1629 (London: Longman, 1884), 10.

85. Sainsbury, Calendar, 15; also cited in Neville-Sington, "Purchas his Pilgrimes (1625), $" 532$.

86. Sainsbury, Calendar, 15; also, Neville-Sington, "Purchas his Pilgrimes (1625)," 532, citing India Office Records, B/9, 315 .

87. Ibid.

88. Neville-Sington, "Purchas his Pilgrimes (1625)," 532.

89. Ibid., 534 . 
the printer, and there would have been no reason to suppose they would not have taken the same approach with the binder. Using the bookbinder as a pretext for his own anxieties only to be caught out by the Company sending its agents to bribe the bookbinder had the potential to be very embarrassing, given Purchas's use of the Company's materials. Whatever actually happened, it is clear that Purchas's discourse of a bookbinder objecting to a text and refusing to bind it was a believable one for his contemporaries. It suggests that bookbinders did not always smooth the way from printed sheets to bound books and that the fear of reprisals, notwithstanding the licenser's agreement, influenced the production of the text.

There were a variety of circumstances under which bookbinders in the early modern period may not have been as willing as authors, patent holders, and customers might have liked to bring books to market. Obstructionism took a variety of forms, including using poor quality materials and engaging in deceitful binding; resisting and ignoring patents; and, on very rare occasions, textual suppression. Despite being apparently counter-intuitive, such actions derived from a range of causes: the unavailability of materials, financial hardship, and sometimes just plain deceit; a perception of potentially greater losses being incurred by following instructions and obeying patents; the fear of reprisal for binding offensive material, and an evaluation that such work was not worth the risk. Although more books did successfully negotiate the bookbinders than failed to do so, it is clear that book production was not always an untroubled process. Not only did authors have to negotiate the licensers, compositors, and pressmen, but they also had to be sure that the binder would play their part. Usually, they did, but at times they used their position to seek better conditions and financial reward, to protect their interests, and prevent prosecution. As such, bookbinders were not silent producers of texts who lacked agency; rather, they were, at times, difficult, impecunious, and obstructive members of a trade where the risks might outweigh the rewards. In such circumstances they might be content that a book should be not bound but gagged. 